\title{
포도막수막증후군 2예
}

\section{Two Cases of Uveo-meningeal Syndrome}

\author{
한동균 · 경성은 \\ Dong Kyun Han, MD, Sung Eun Kyung, MD, PhD \\ 단국대학교 의과대학 안과학교실 \\ Department of Ophthalmology, Dankook University College of Medicine, Cheonan, Korea
}

\begin{abstract}
Purpose: We report two cases of uveo-meningeal syndrome involving the retina, uvea, and optic disc in both eyes after viral meningitis.

Case summary: A 16-year-old female was referred to our department with blurred vision in both eyes. She was hospitalized in the pediatric ward with viral meningitis. She showed a norma best-corrected visual acuity (BCVA) and normal intraocular pressure in both eyes, but had severe inflammation in the anterior chamber on slit lamp examination, and optic disc edema and multiple whitish lesions on fundus examination. She was treated with intravenous antibiotic injections and steroid eye drops. After close observation, inflammation in the anterior chamber, optic disc edema, and the multiple whitish lesions in the retina were improved. A 27-year-old male who was treated for viral meningitis at the neurology department was referred to us with blurred vision in both eyes. His BCVAs were 0.7 (right eye) and 0.6 (left eye). The intraocular pressure was normal in both eyes. Slit lamp examination revealed inflammation in the anterior chamber and optic disc edema, and a fundus examination revealed multiple infiltrations. He received treatment for presumed herpes virus infection. After close observation, inflammation in the anterior chamber, optic disc edema, and multiple infiltrations with hemorrhage in the retina were improved.
\end{abstract}

Conclusions: Clinicians should consider the possibility of uveo-meningeal syndrome, which can cause inflammation in the uvea,retina, and optic disc simultaneous with viral meningitis accompanying blurred vision.

J Korean Ophthalmol Soc 2019;60(3):292-297

Keywords: Meningitis, Viral, Vision disorder, Uveo-meningeal syndrome

포도막수막증후군(uveo-meningeal syndrome)은 포도막, 망막, 뇌막을 침범하는 다양한 유형의 질환으로 중추신경 계통의 이상 증상과 동반된 포도막과 유리체의 염증, 망막

\footnotetext{
- Received: 2018. 7. 5.

- Accepted: 2019. 2. 20.

- Revised: 2018. 9. 3.

- Address reprint requests to Sung Eun Kyung, MD, PhD Department of Ophthalmology, Dankook University Hospital, Dankook University College of Medicine, \#119 Dandae-ro, Dongnam-gu, Cheonan 31116, Korea

Tel: 82-41-550-6497, Fax: 82-41-550-6894

E-mail:kseeye@hanmail.net

* Conflicts of Interest: The present research was conducted by the research fund of Dankook University in 2018.
}

의 출혈이나 염증 등으로 인한 시력저하의 임상양상을 보 인다. 포도막수막증후군은 크게 탈수초성 질환, 감염, 염증, 신생물성 반응에 의해 발생하는 것으로 알려져 있고, 그 원 인 질환에 따라 특징적인 발현을 보인다고도 알려져 있다. ${ }^{1}$ 그중에서 가장 잘 알려진 것은 보크트-고야나기-하라다증 후군(Vogt Koyanagi Harada syndrome)으로 피부백반, 탈모 증, 백모증과 같은 피부과적 증상과 뇌막자극증상, 이명, 양 측성 육아종성 범포도막염, 장액망막박리, 유두부종 등을 보인다. ${ }^{2}$ 북아메리카인들을 대상으로 한 연구에서 포도막 염을 앓고 있는 사람 중 $8 \%$ 에서 신경학적 증상을 동반한다 는 보고가 있으며, 포도막염과 중추신경 질환이 빈번하게 동시에 발생하는 이유는 망막, 시신경, 포도막 등의 눈의 후부 
분절과 중추신경계가 공통적으로 신경외배엽(neuroectoderm) 에서 기원하기 때문으로 알려져 있다. ${ }^{3}$ 또한 뇌수막도 신경 외배엽에서 기원한 신경능(neural crest)과 중배엽(mesoderm) 에서 동시 기원하는 것으로 알려져 있다. ${ }^{4}$ 혈액-뇌 장벽과 혈액-망막 장벽의 유사성, 눈과 중추신경계가 공통적으로 가지고 있는 면역 특권(immune privilege)이 두 기관의 공 통적 기원을 뒷받침해준다. ${ }^{5}$

미코플라스마폐렴 뇌수막염 이후 양안에 중간 포도막염, 망막 출혈이 발생한 사례 ${ }^{6}$ 와 세균뇌수막염 이후 양안에 전 방 포도막염이 발생한 사례 ${ }^{7}$ 가 보고된 적이 있고 국내에서 는 2017년 바이러스뇌수막염 이후 단안에 발생한 포도막염 과 망막급성괴사 사례가 보고된 적이 있으나 ${ }^{8}$ 양안에 발생 한 포도막, 망막, 시신경병변의 사례는 보고된 바가 없다. 본 연구는 바이러스뇌수막염으로 타과 치료 이후 진단된 포도막수막증후군 2예를 보고하고자 한다.

\section{증례보고}

증례1

16세 여자환자가 두통과 발열, 귀 먹먹함 증상으로 소아 과에 내원하여 바이러스뇌수막염 진단하에 치료 후 양안 시력저하 증상 있어 안과로 내원하였다. 소아과 내원 중 시 행한 검사상 뇌척수액검사에서 림프구의 비율이 $58 \%$, protein $53 \mathrm{mg} / \mathrm{dL}$ 로 상승해 있는 소견 및 glucose $47 \mathrm{mg} / \mathrm{dL}$ 로 조금 감소해 있는 소견과 혈중 단순헤르페스바이러스(herpes simplex virus, HSV)의 immunoglobulin G (IgG) (titer 25.4), $\operatorname{IgM}$ 항체(titer 1.1)가 양성인 소견을 보였으며 HSV 1, 2형 중합효소 연쇄반응(polymerase chain reaction, PCR)에서 음성 소견을 보였다. 환자 뇌수막염 발병 이전의 특이 과거 력은 없으나 내원 약 4년 전 친조부가 활동성 결핵을 진단 받았을 당시 접촉했던 과거력이 있었고, 결핵균 특이항원 자극검사(imterferon gamma, IFN- $\gamma$ ) 양성 소견을 보였다.
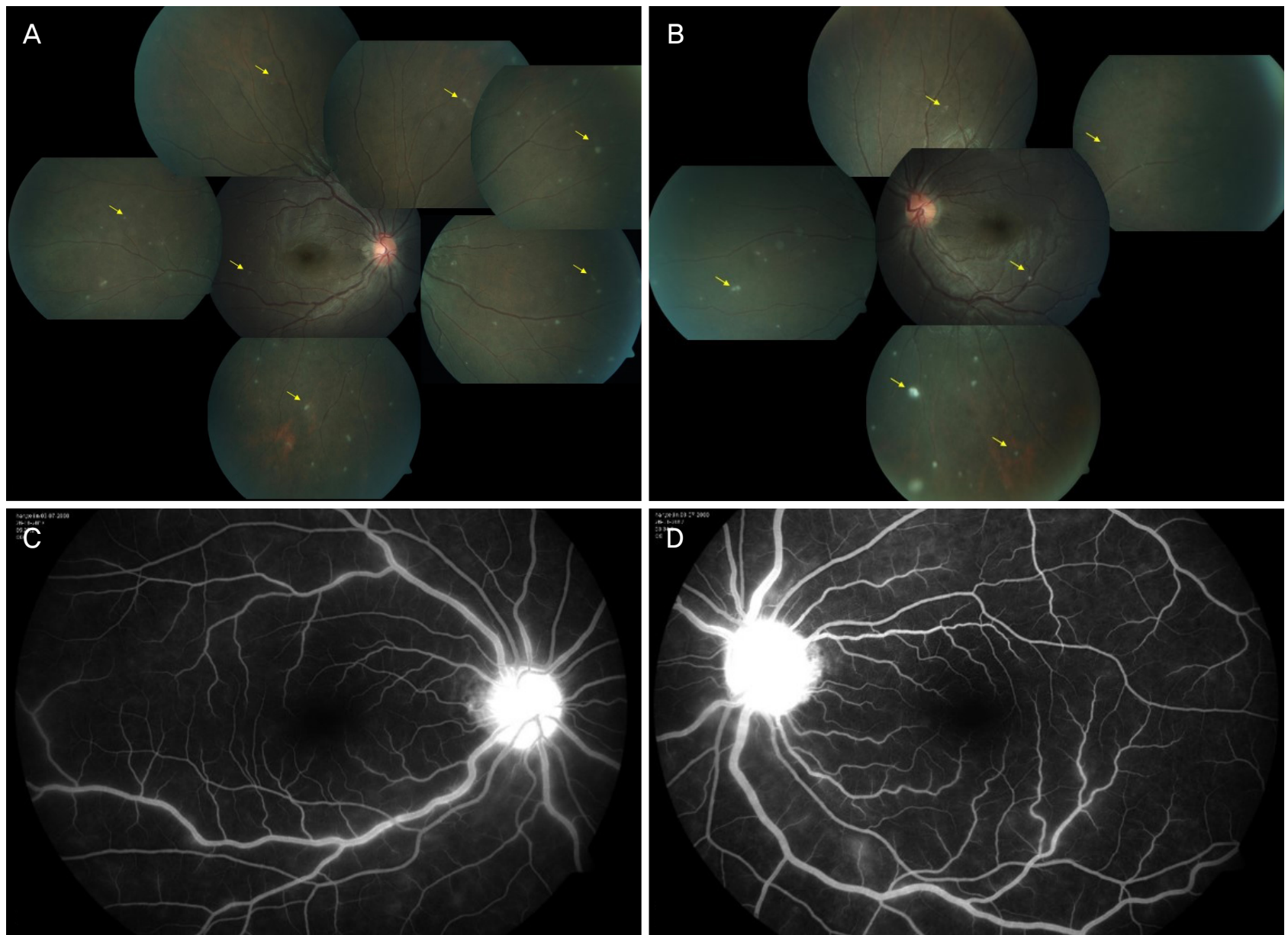

Figure 1. Color fundus photo of the first case. Right (A), left (B), both fundus photos showed multiple whitish lesions (arrows) and mild optic disc swelling. Fluorescence angiography (FAG) of the first case. Right (C, at 02:01.0), left (D, at 05:38.3). Both eyes showed vascular leakage in FAG and there were no hyperfluorescent lesions. 

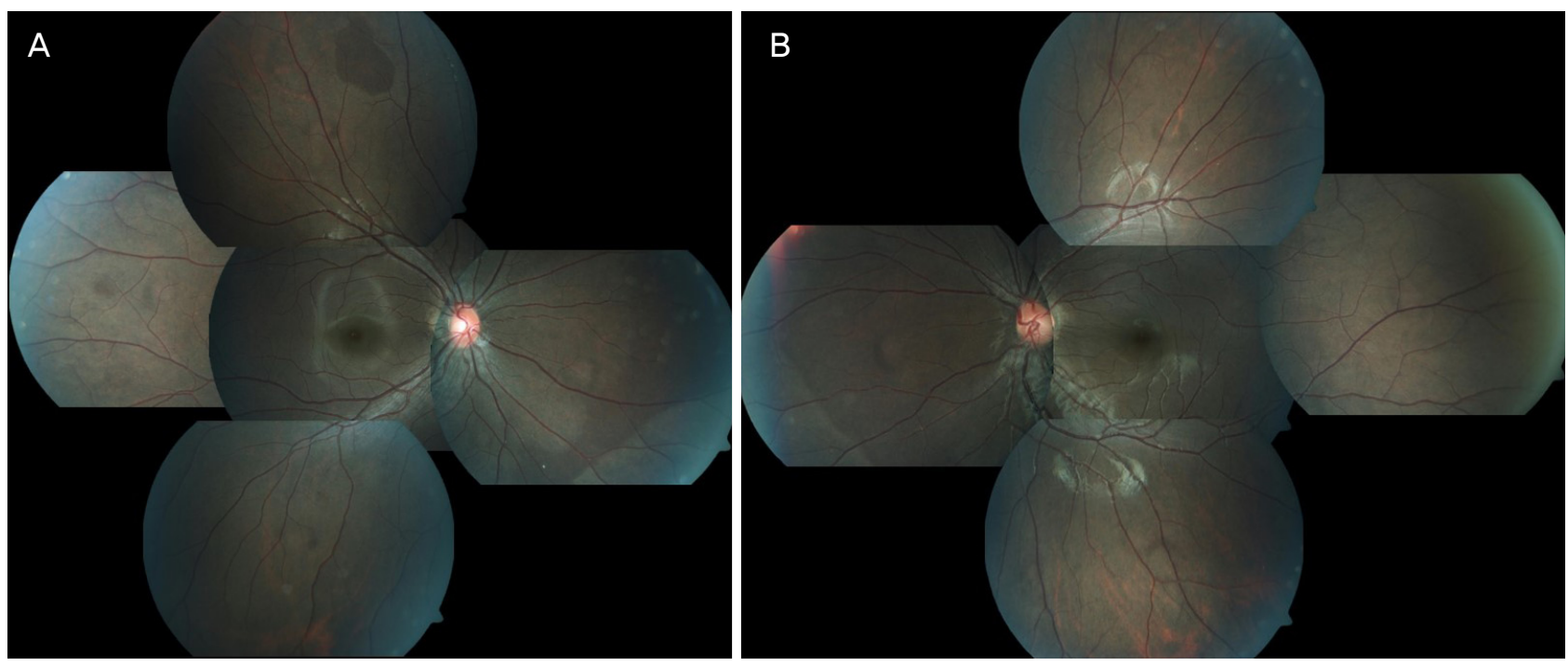

Figure 2. Color fundus photos of the first case at 7 months later in right (A), left (B) eyes. Both photos showed disappearance of whitish lesions and normal optic disc.

안과 초진 당시 최대교정시력은 우안 1.0 , 좌안 1.0 이었으 며, 안압은 우안 $12 \mathrm{mmHg}$, 좌안 $12 \mathrm{mmHg}$ 측정되었다. 세 극등현미경검사상 양안 전방 내 염증세포 4+ 소견을 보였 고, 안저검사상 양안의 시신경유두부종 소견과 망막 주변 부에 둥근 황백색의 반점들이 관찰되었다(Fig. $1 \mathrm{~A}, \mathrm{~B})$. 형 광안저촬영을 시행하였고 형광안저촬영에서 망막혈관의 형 광 유출을 보였다(Fig. 1C, D). $1 \%$ prednisolone acetate를 양안에 하루 6 회 점안하며 5 일 뒤 경과 관찰하였고, 5 일 뒤 환자의 양안 교정시력은 1.0 측정되고 우안 안압 $13 \mathrm{mmHg}$, 좌안 안압 $15 \mathrm{mmHg}$ 으로 측정되었으며, 전방 내 염증 및 시신경유두부종 소견도 감소하였고 2주 뒤 전방 내 염증 및 시신경유두부종 소견도 호전되었다(Fig. 2).

\section{증례2}

특이 과거력 없는 27 세 남자환자가 15 일 전부터 발생한 두통, 발열 등의 증상으로 타 병원 신경과에서 바이러스뇌 수막염 진단하에 치료하여 퇴원한 후 내원 7일 전부터 발 생한 양안이 흐리게 보이는 증상으로 안과로 내원하였다. 뇌수막염 진단 당시 뇌척수액검사에서 림프구의 비율이 $100 \%$ 이며 혈청검사 및 바이러스 PCR검사상 이상 소견이 없었다. 안과 검사상 최대교정시력은 우안 0.7 , 좌안 0.6 , 안 압은 우안 $12 \mathrm{mmHg}$, 좌안 $12 \mathrm{mmHg}$ 이었다. 세극등현미경 검사상 양안 전방 내 염증세포 $2+$ 가 관찰되었고, 안저검사 상 양안의 시신경부종 및 망막의 후극부 및 주변부에 다수 의 황백색 침윤 및 출혈 소견이 관찰되었다(Fig. 3).

망막 출혈 소견이 도안되어 헤르페스바이러스 감염의 가 능성을 고려하여 7일간 경구 acyclovir 1,200 mg을 하루 3회
에 분할 복용하는 치료를 시행했고 이후 양안 전방 내 염증 소견과 시신경부종, 망막 주변부의 황백색 침윤 소견이 호전 되었다. 3 개월 뒤 양안 교정시력 1.0 , 우안 안압 $13 \mathrm{mmHg}$, 좌안 안압 $12 \mathrm{mmHg}$ 이 측정되었으며 전방에 염증세포 없 으며 망막출혈 및 시신경부종은 호전되었다(Fig. 4).

\section{고 찰}

본 두 증례는 바이러스뇌수막염과 동반되어 양안의 포도 막과 유리체의 염증, 망막의 출혈, 시신경의 부종으로 시력 저하를 보인 포도막수막증후군의 증례들이다. 포도막수막 증후군 중 보크트-고야나기-하라다증후군, 중추신경계 림 프종, 다발경화증, 헤르페스바이러스 감염 등은 빈번하게 발생한다고 알려져 있다. ${ }^{9}$ 보크트-고야나기-하라다증후군 은 이 중 가장 흔하게 발생하며 멜라닌 합성에 필요한 타이 로시나아제(tyrosinase) 및 tyrosinase-related protein 1, 2에 작용하는 자가면역 질환으로 색소세포가 배아발생단계에 서 신경능(neural crest)에서 기원하여 피부, 맥락막, 내이 (inner ear), 연수막 등으로 이동하여 피부백반, 탈모증, 백 모증과 같은 피부과적 증상과 뇌막자극증상, 이명, 양측성 육아종성 범포도막염, 장액망막박리, 유두부종 등을 보이게 된다. 중추신경계 림프종과 탈수초성 질환인 다발경화증이 중추신경계와 눈의 후부분절에 동시 이환되는 것은 혈액뇌 장벽과 혈액-망막 장벽의 유사성, 눈과 중추신경계가 공 통적으로 가지고 있는 면역 특권(immune privilege)으로 설 명되고 헤르페스바이러스가 포도막수막증후군을 일으키는 기전이 정확히 알려져 있지는 않지만 굴성(tropism)을 가진 

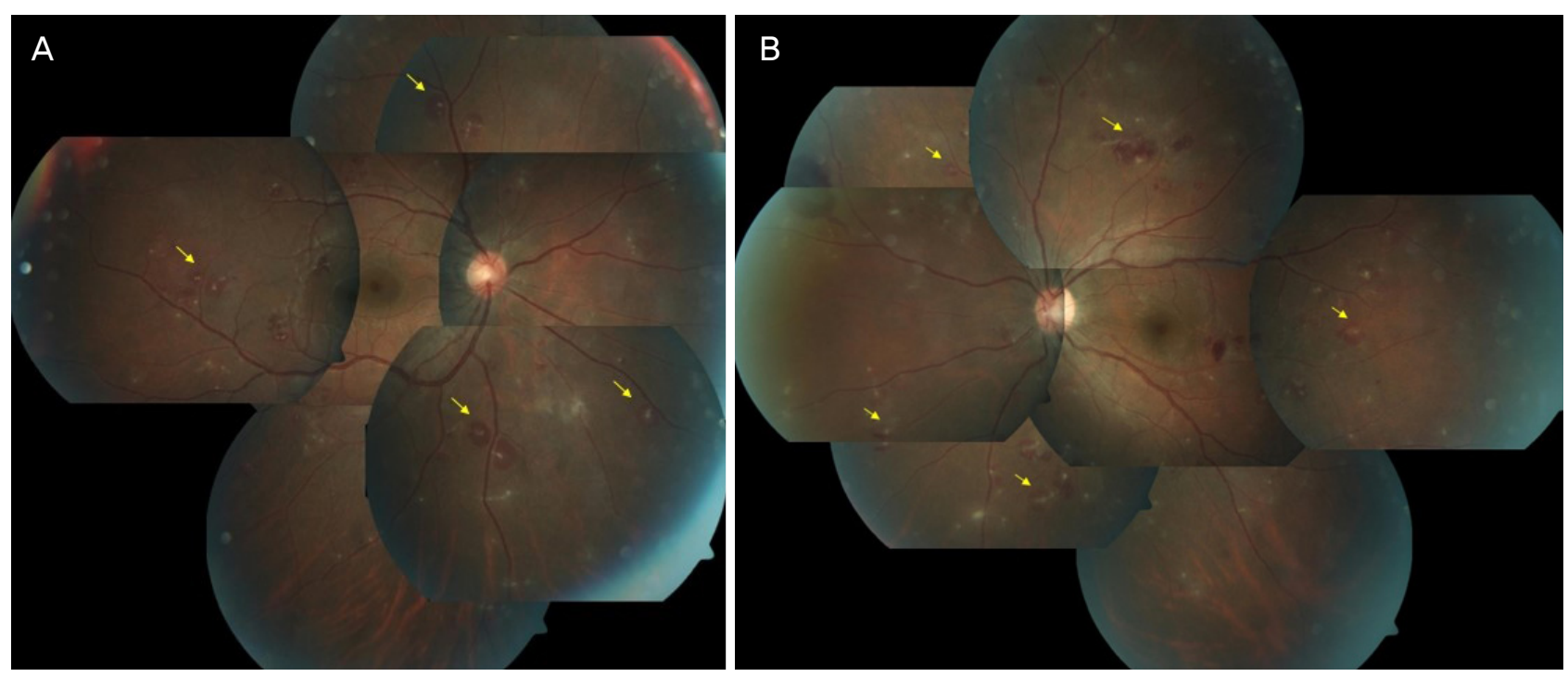

Figure 3. Color fundus photo of the second case. Right (A), left (B), both fundus photos showed multiple infiltrations with hemorrhage (arrows) and optic disc swelling.
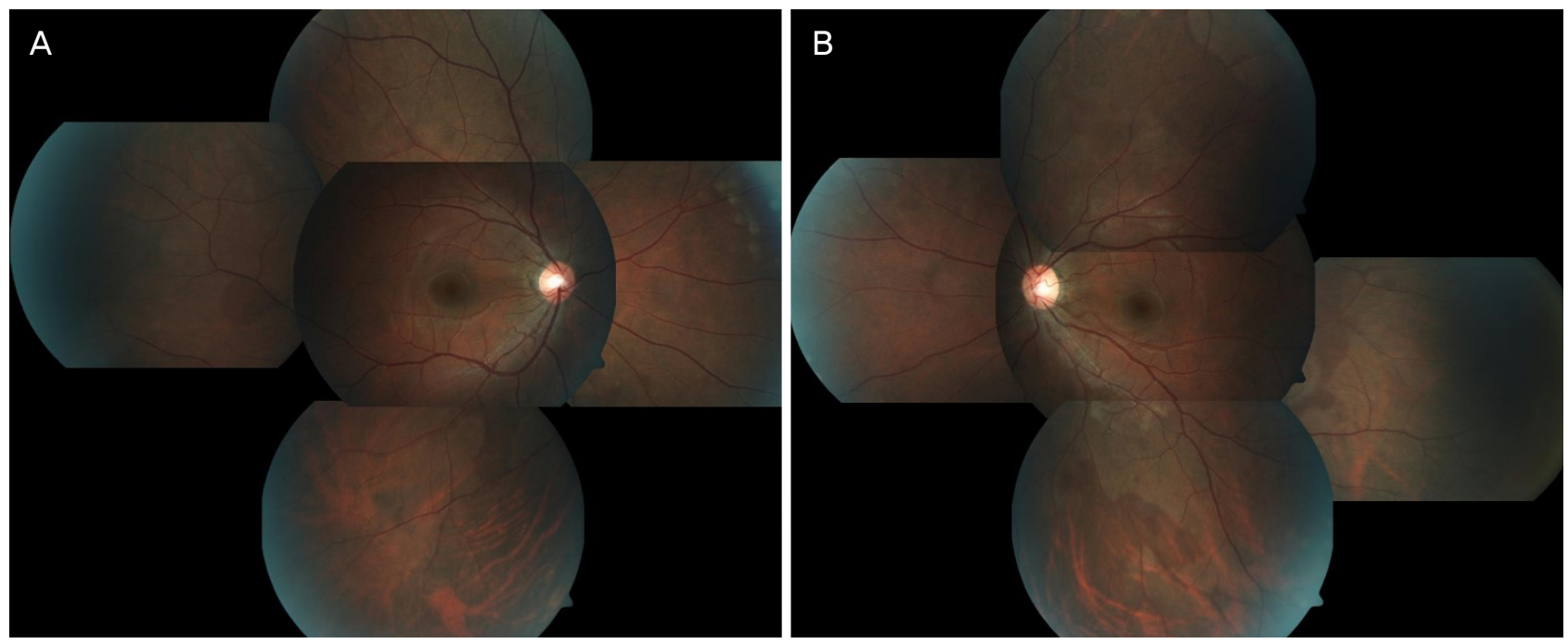

Figure 4. Color fundus photo of the second case at 3 months later in the right (A), left (B) eyes. Both photos showed disappearance of infiltrations and hemorrhage and normal optic disc.

헤르페스바이러스가 공통적인 기원을 가진 두 기관 사이를 감각 신경절(sensory ganglia)을 통해 전파하는 것으로 추측 된다. ${ }^{5}$ 두 증례 모두 안과적 증상이 발생하기 전에 뇌수막 염의 기왕력이 있었던 상태로 전방천자검사를 시행하여 원 인 바이러스를 확인할 수는 없었다. 첫 번째 증례에서 시행한 뇌척수액검사에서 림프구의 비율이 $58 \%$, protein $53 \mathrm{mg} / \mathrm{dL}$ 으로 상승, glucose $47 \mathrm{mg} / \mathrm{dL}$ 로 감소해 있는 소견과 혈중 $\mathrm{HSV}$ 의 $\operatorname{IgG}, \operatorname{IgM}$ 항체가 양성으로 나와 HSV 뇌수막염을 의심할 수 있었으나, 급성기 HSV 감염을 나타내는 $\mathrm{HSV}$ $\operatorname{IgM}$ titer가 1.1로 낮고 $\mathrm{HSV} 1,2$ 형 PCR에서 음성 소견을
보였다. 환자는 약 4년 전 친조부가 활동성 결핵을 진단받 았을 당시 접촉했던 과거력이 있었고, 결핵균 특이항원자 극검사(IFN- $\gamma$ ) 양성 소견을 보여 잠복결핵으로 퇴원 이후 결핵약을 3 개월간 복용하던 중이었으며, 병변은 2주만에 없어져서 본 증례는 결핵과 관련된 망막의 염증은 아닌 것 으로 생각되었다. 본 증례에서 보이는 포도막염 및 망막의 경계가 잘 지어진 많은 황백색 반점들은 급성망막괴사, 급 성 후부 다발 판모양 색소상피증(acute posterior multifocal placoid pigment epitheliopathy), 또는 소실성다발흰점증후 군(multiple evanescent white dot syndrome) 등의 흰점증후 
군(white dot syndromes)을 감별 진단으로 고려하여야 한다. 흰점증후군의 감별에는 형광안저촬영과 망막자가형광촬영 (fundus autofluorescence), 인도시아닌 안저촬영(indocyanine green angiography) 등의 검사가 도움이 될 수 있다. 형광안 저촬영의 경우 급성 후부 다발 판모양 색소상피증은 흰반 점병변이 초기에 저형광을 보이다가 후기로 갈수록 과형광 을 보이며 소실성다발흰점증후군은 초기부터 후기까지 과 형광을 보이는 소견이 특징적이나 ${ }^{10}$ 본 증례에서는 형광안 저촬영상 망막 혈관의 형광유출 외 다른 이상은 보이지 않 았다. 또한 급성 후부 다발 판모양 색소상피증의 경우는 병 변이 좀 더 큰 특징을 보이고 소실성다발흰점증후군의 경 우는 뇌수막염을 동반하는 경우가 거의 없으며 헤르페스바 이러스 뇌수막염 발생과 연관되어 나타난 급성망막괴사로 진단하기에는 PCR검사상 확인되지 않았으며 경도의 망막 염 소견을 보이며 항바이러스제제를 쓰지 않고 항생제와 스테로이드 치료로 2주만에 호전되었다는 점에서 맞지 않 는 소견으로 생각된다. 따라서 본 증례는 원인 바이러스를 확인할 수 없는 바이러스뇌수막염에 동반된 포도막수막증 후군으로 생각된다.

두 번째 증례의 경우 타 병원에서 바이러스뇌수막염을 진단받은 경우로 뇌척수액검사에서 림프구의 비율이 $100 \%$ 이며 혈청검사 및 바이러스 PCR검사상 음성 소견을 보였 다. 망막의 후극부 및 주변부에 다수의 황백색 침윤 및 출 혈 소견을 보여 PCR 음성 소견을 보였으나 헤르페스바이 러스에 의한 가능성을 배제할 수 없어 경구 acyclovir 복용 을 시작하였다. Vandercam at $\mathrm{el}^{11}$ 은 뇌염과 동반된 급성망 막괴사를 유발하는 원인으로 HSV type 1, 2 (57.1\%)와 수 두대상포진바이러스(varicella-zoster virusm, VZV) (28.6\%) 의 비중이 높다는 것을 보고하였고 본 증례에서는 원인 바 이러스를 감별할 자료가 부족하였지만 거대세포바이러스 (cytomegalovirus, $\mathrm{CMV}$ ) 감염은 환자의 면역상태가 저하되 지 않았다는 점과 몇 주나 몇 달에 걸쳐 망막의 괴사가 심 해지는 CMV retinitis의 특징적인 질병의 양상을 고려할 때 배제할 수 있었다. 중증의 급성망막괴사를 보이는 환자에 서 급성의 $\mathrm{HSV}$ 또는 $\mathrm{VZV}$ 감염이 의심되는 경우 경구 acyclovir가 drug of choice이고 그 외 valaciclovir, famciclovir 복용을 고려해 볼 수 있다. ${ }^{12}$ 바이러스뇌수막염과 동반된 급성망막괴사의 사례 역시 상당히 드물어 유병률이 보고된 적은 없으나 양안에 발생하는 사례는 3 명 중에 1 명 꼴이라 고 보고된 적이 있다. ${ }^{13}$ 두 번째 증례의 경우는 망막에 다수 의 황백색 침윤 및 출혈 소견이 심하지 않았으며 PCR검사
상 음성 소견을 보였다. 안과 내원 후 경구 acyclovir $1,200 \mathrm{mg}$ 을 하루 3회 분할 복용하는 치료 7일 만에 호전되고, 3달 후 정상 소견을 보여 헤르페스바이러스에 의한 망막괴사로 생각되지는 않았다. 두 증례 모두 바이러스뇌수막염 이후 망막염, 포도막염, 시신경부종이 관찰된 경우이며 원인은 확인할 수는 없었지만, 바이러스뇌수막염 이후 발생한 병 변으로 포도막수막증후군으로 진단되었다. 눈과 중추신경 계에 염증을 일으키는 많은 질환들이 있으며 신경학적인 증상 없이 포도막염으로 내원한 환자의 경우이거나 본 증 례처럼 뇌수막염을 진단받았거나 두통이나 발열 등의 신경 학적 증상을 호소하며 침침함을 주소로 내원할 경우 포도 막수막증후군의 가능성을 고려하여 시력저하가 없는 경우 에도 적절한 진단 및 치료가 이뤄져야 할 것으로 생각된다.

\section{REFERENCES}

1) Brazis PW, Stewart M, Lee AG. The uveo-meningeal syndromes. Neurologist 2004;10:171-84.

2) Lavezzo MM, Sakata VM, Morita C, et al. Vogt-Koyanagi-Harada disease: review of rare autoimmune disease targeting antigens of melanocytes. Orphanet J Rare Dis 2016;11:29.

3) Heavner W, Pevny L. Eye development and retinogenesis. Cold spring Harb Perspect Biol 2012;4:a008391.

4) Decimo I, Fumagalli G, Berton V, et al. Meninges: from protective membrane to stem cell niche. Am J Stem cells 2012;1:92-105.

5) Allegri P, Risotto R, Herbort CP, Murialdo U. CNS disease and uveitis. J Ophthalmic Vis Res 2011;6:284-308.

6) Yashar SS, Yashar B, Epstein E, Viani RM. Uveitis associated with Mycoplasma pneumonia meningitis. Acta Ophthalmol Scand 2001:79:100-1.

7) Otomo K, Kaburaki T, Shigeeda T, et al. Bilateral anterior uveitis in a patient with bacterial meningitis. Int Ophthalmol 2012:32:401-3.

8) Park WK, Baek JW, Ra H. Two cases of acute retinal necrosis after viral meningitis. J Korean Ophthalmol Soc 2017:58:1295-300.

9) Smith JR, Rosenbaum JT. Neurological concomitants of uveitis. $\mathrm{Br}$ J Ophthalmol 2004;88:1498-9.

10) Williams DF, Mieler WF. Long-term follow-up of acute placoid multifocal posterior placoid pigment epitheliopathy. Br J Ophthalmol 1989;73:985-90.

11) Vandercam T, Hintzen RQ, de Boer JH, Van der Lelij A. Herpetic encephalitis is a risk factor for acute retinal necrosis. Neurology 2008;71:1268-74.

12) Rautenberg P, Hillenkamp J, Grančičova L, et al. Virus diagnostics and antiviral therapy in acute retinal necrosis (ARN). In: Arbuthnot P, ed. Antiviral Drugs, 1st ed. Rijeka: InTech, 2012;17-34.

13) Gatry DS, Spalton DJ, Tilzey A, Hykin PG. Acute retinal necrosis syndrome. Br J Ophthalmol 1991;75:292-7. 


\section{$=$ 국문초록 $=$}

\section{포도막수막증후군 2예}

목적: 바이러스뇌수막염 이후 양안에 망막, 포도막, 시신경을 침범한 포도막수막증후군 2예를 보고하고자 한다.

증례요약: 16 세 여자환자가 소아과에서 바이러스뇌수막염 진단하에 치료 후 양안 시력저하로 내원하였다. 최대 교정시력은 우안 1.0, 좌안 1.0 , 안압 정상이었다. 양안은 세극등현미경검사상 전방 내 염증이 심하였고, 안저검사상 시신경유두부종 소견, 망막 주변부의 다발성 황백색의 병변도 보였다. 항생제 정맥 주사, 스테로이드 안약 치료 후 전방 내 염증, 시신경유두부종, 망막의 황백색병변이 호전되었다. 27세 남자환자가 신경과에서 바이러스뇌수막염 진단하에 치료 후 양안 흐리게 보여 내원하였다. 최대교정시력 우안 0.7 , 좌안 0.6, 안압 정상이었다. 양안은 세극등현미경검사상 전방 내 염증 소견, 안저검사상 시신경유두부종, 망막출혈 및 망막염 소견을 보였다. 헤르페스바이러스 감염의 가능성이 높아 경구 아시클로버, 스테로이드 안약 치료 후 전방 내 염증, 망막 출혈 및 망막염 소견 이 호전되었다.

결론: 뇌수막염을 진단받은 환자가 양안 흐림을 호소 시 포도막, 망막, 시신경에 염증을 일으키는 포도막수막증후군의 가능성을 고려 해야 한다.

〈대한안과학회지 2019;60(3):292-297〉

한동균 / Dong Kyun Han

단국대학교 의과대학 안과학교실

Department of Ophthalmology,

Dankook University College of Medicine

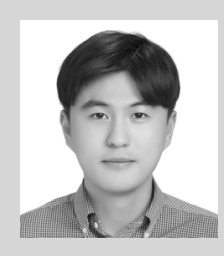

